\title{
Toxicology of microbial toxins
}

\author{
Yoshio Ueno \\ Department of Toxicology and Microbial Chemistry, Faculty of Pharmaceutical \\ Sciences, Tokyo University of Science, Tokyo, Japan
}

\begin{abstract}
Algal and fungal toxins comprise a wide array of naturallyoccurring toxic compounds in the aquatic and terrestrial environment. An association between these microbial toxins and human health has existed since biblical times when ergotism was assumed to be a toxicosis that resulted from the ingestion of such natural toxins. During the past several decades, the existence and significance of these intoxications were recognized and the chemical features and molecular mechanism of their toxic action, in particular, were elucidated. This chapter is an attempt by the author to summarize current information on the toxicological behavior of mycotoxins and phycotoxins, mainly from the view of their molecular mechanism of action. Since most of the fungal and algal toxins belong to a group of small molecular weight organic compounds, it is important also to summarize their biological transformations. Based on their pharmacological and toxicological characteristics, these toxins are classified as: 1) inhibitors of energy production; 2) inhibitors of protein synthesis; 3) cytoskeleton modifiers; 4) mutagenic and carcinogenic compounds; 5) ion-channel blockers; and others. These analyses revealed that the microbial toxins are excellent tools for the research and characterization of biological phenomena.
\end{abstract}

\section{MYCOTOXINS}

\section{A Inhibitors of energy production}

\section{A.l. Citreoviridin and related $\alpha$-pyrone derivatives}

Citreoviridin (CV) (Fig. l) is a mycotoxin produced by Penicillium citreoviride Biourge $P$. ochrasalmoneum Udagawa, and $P$. pulvillorum. This toxin was initially separated from the metabolites of $P$. citreoviride strains associated with cases of cardiac beriberi (Shoshin-kakke in Japanese). During the last three centuries this disease has been prevalent in rice-eating countries (including Japan), with characteristic signs such as vomiting, convulsions, ascending paralysis, and respiratory arrest. The extensive research by Uraguchi (ref. l) has revealed that an alcoholic extract of yellow rice, infected with this fungus, and the mycotoxin (CV) produced by this fungus, induced clinical signs in animals similar to those of cardiac beriberi in man.

The $L_{50}$ values of $\mathrm{CV}$ in male mice were 11 (scbcutaneous), 7.5 (intra-peritoneal), and 29 (per os) $\mathrm{mg} / \mathrm{kg}$, respectively. Progressive paralysis of the ascending type due to spinal and medullary depression develops since the toxin affects the motor neurons or internuncial neurons along the spinal cord. Chemically speaking, the structure of CV is very similar to aurovertin B of Calcarisporium arbuscula and asteltoxin of Aspergillus stellatus and Emericella variecolor (Fig. 1). The $L_{50}$ of asteltoxin is $5 . \overline{9 g} / \mathrm{kg}$ in<smiles>COc1cc(=O)oc(/C=C/C=C/C=C/C(C)=C/[C@@]2(C)OC(C)[C@](C)(O)[C@H]2O)c1C</smiles><smiles>CCC1OC2(C)C(OC(C)=O)C(C)(C)C1(C)O[C@H]2/C=C/C=C/C=C/c1oc(=O)cc(OC)c1C</smiles><smiles>CCC1O[C@H]2O[C@H](/C=C/C=C/C=C/c3oc(=O)cc(OC)c3C)[C@@H](O)C2(C)[C@@]1(C)O</smiles>

Fig. 1. $\alpha$-Pyrone derivatives 
mice; paralysis of hind legs and respiratory impairment are the major clinical signs. All these toxins are potent inhibitors of the energy transfer reaction coupled with oxidative phosphorylation in mitochondria. The mode of action is presumed to be the binding of these mycotoxins to, and the change in conformation of, the mitochondrial ATP-ase sub-units (ref. 2).

\section{A.2 Luteoskyrin, emodin, averufin and other anthraquinones}

Luteoskyrin (LT) is a hepatotoxic and hepatocarcinogenic mycotoxin produced by Penicillium islandicum Sopp. Besides this bis-anthraquinone (LT), the fungus also produces more than a dozen other polyhydroxyanthraquinones such as rugulosin, skyrin, emodin and others (Fig. 2) (ref. 3). LT and rugulosin possess a high affinity for mitochondria, and have a potent uncoupling action. Current research has revealed that averufin, a metabolic precursor of aflatoxin $B_{1}$ and sterigmatocystin, uncoupled oxidative phosphorylation, causing 50\% uncoupling at about $1.5 \mathrm{nM}$ with respect to the decrease in the $\mathrm{P} / 0$ ratio (ref. 4).

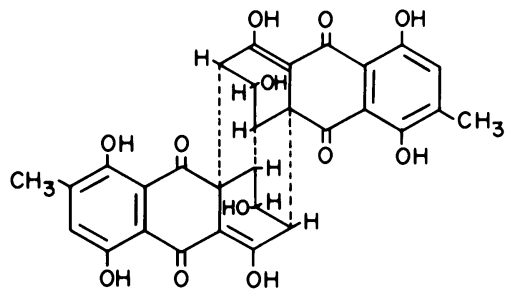

$(-)$ Luteoskyrin<smiles>Cc1cc(O)c2c(c1)C(=O)c1c(O)cc(O)c(-c3c(O)cc(O)c4c3C(=O)c3c(O)cc(C)cc3C4=O)c1C2=O</smiles>

Skyrin

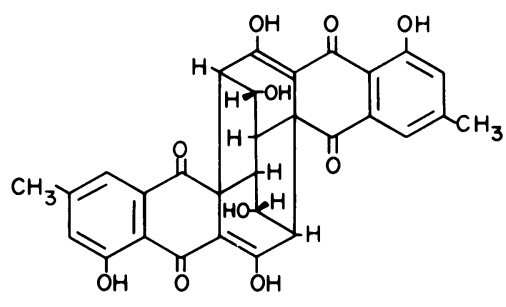

(+) Rugulosin<smiles>CCOC(=O)c1cc(C)cc(O)c1C(=O)c1cc(O)cc(O)c1</smiles><smiles>Cc1cc(O)c2c(c1)C(=O)c1cc(O)c(O)c(O)c1C2=O</smiles>

2-Hydroxyemodin

Fig. 2. Polyhydroxyanthraquinoid mycotoxins

\section{A.3. Xanthomegnin, secalonic acids and xenoclauxin}

Xanthomegnin is a naphthoquinone produced by several pathogenic fungi such as Trichophyton megnini and $P$. viridicatum. The natural occurrence of xanthomegnin has been established. These mycotoxins (Fig. 3) are hepatotoxic in experimental animals, and give rise to an electron transport shunt from NADH dehydrogenase to cytochrome $c$ in the mitochondrial electron transport chain (ref. 5). Secalonic acid (SA) D was first isolated from P. oxalicum, and $S A-A$, the antipode of $S A-D$, was isolated from A. ochraceus. SA-D is teratogenic and mutagenic. The 1- or 8-hydroxy group or both in the xanthone ring could release protons at a physiological $\mathrm{pH}$. This chemical feature may explain the uncoupling action of this mycotoxin. Xenoclauxin, an oxaphenalenone dimer of $P$. duclauxii, also causes its cytotoxicity by a potent uncoupling action (ref. 6).<smiles>COC1=C([Te])C(=O)c2c(cc3c(c2O)C(=O)O[C@@H](C)C3)C1=O</smiles>

Xanthomegnin<smiles>[Y]c1ccc2c(c1O)C(=O)C1=C(O)CC(C)[C@](C)(O)[C@]1(C(=O)O)O2</smiles>

Secalonic acid $D$<smiles>COC(=O)[C@@]12Oc3ccc([Te])c(O)c3C(=O)C1=C(O)C[C@H](C)[C@H]2OC</smiles>

Secalonic acid A

Fig. 3. Secalonic acids and xanthomegnin 
A. 4. Moniliformin

Moniliformin (MF) (Fig. 4) is a toxic principle of Fusarium moniliforme, a pathogenic fungus of corn and other cereals (ref. 7). A rapidly progressive muscular weakness, sternal recumbency, abdominal respiration, coma, and death are the major clinical signs in rats given MF orally. This mycotoxin, similar to arsenide, is a potent inhibitor of the mitochondrial pyruvate and $\alpha$-ketoglutarate oxidation reactions (ref, 8 ).

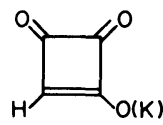

Fig. 4. Moniliformin

\section{B Inhibitors of protein synthesis}

\section{B.1. Ochratoxin A}

Ochratoxin A (OA) and related toxins were isolated from A. ochraceus, A. seleotiorum, P. viridicatum, $P$. cyclopium, and others (ref. 9). Among several derivatives, OA is the major and most toxic metabolite. Both $O A$ and $O B$ (dechloro analog of $O A$ ) have been found as natural contaminants in food, feed, and their processed products. A close relationship between endemic (Balkan) nephropathy and OA contamination in Denmark and other countries has been suggested (ref. 9). The $L_{50}$ of $\mathrm{OA}$ (administered per os) varied from 2.1 to 4.67 $\mathrm{mg} / \mathrm{kg}$ for chickens, swine, and trout, and is $22 \mathrm{mg} / \mathrm{kg}$ in female rats. When the dosage rates were similar to naturally-occurring levels of $O A$, the sole target organ is the kidney. Malfunction of the proximal convoluted tubules and depression of phosphoenolpyruvate carboxylase activity are early signs of $\mathrm{OA}$-induced renal damage (ref. 10).

$\mathrm{OA}$ is a potent inhibitor of protein synthesis in bacterial and animal cells, and the competitive inhibition of phenylalanyl-tRNA synthetase is its molecular basis ( $r e f .11$ ). The lethal toxicity as well as its immunosuppressive action is reversed by prior administration of L-phenylalanine.

Hepatic microsomes from various animals transform OA into hydroxylated OAs (ref. 12). Experiments with purified cytochrome P-450s from PCB-pretreated rats, revealed that cytochrome $P-448 \mathrm{~s}$, which possesses a maximal co-differential spectrum at $448 \mathrm{~nm}$, catalyzes the stereospecific hydroxylation at $C-4$ to yield $(4 R)-4-h y d r o x y-0 A$, while cytochrome $P-450$ types produce (4S)-4-hydroxy-0A. It is presumed that the degree of toxicity of (4R)-4hydroxy-OA is comparable to that of the parent $O A$ (ref. 13).

\section{B.2. Trichothecenes}

The trichothecene mycotoxins are a family of closely related sesquiterpenoids produced by fungal genera such as Fusarium, Trichothecium, Trichoderma, Stachybotrys and others. The mycology, toxicology and chemistry of the trichothecenes were recently reviewed ( $r$ ef. 14, $15,16)$.

Of the numerous trichothecenes, T-2 toxin was first isolated from corn associated with outbreaks of moldy corn toxicosis in farm animals in the United States of America. Other surveys have demonstrated that nivalenol/deoxynivalenol are the toxins causing scabby

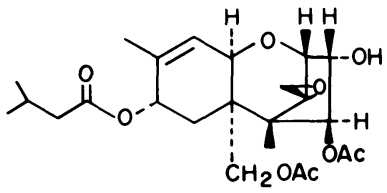

(A) T-2 toxin

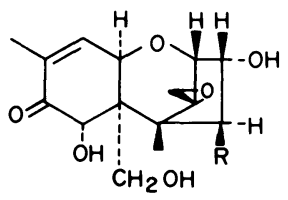

(B) Nivalenol Deoxynivalenol $R=H$

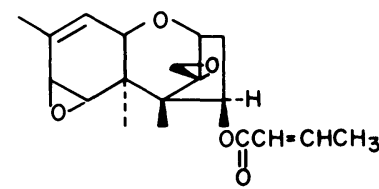

(C) Crotocin

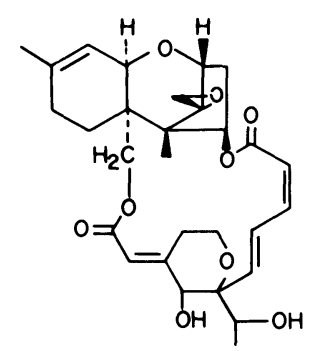

(D) Satratoxin $\mathrm{H}$

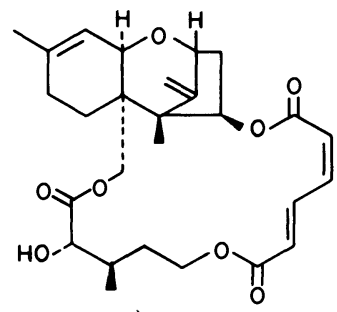

(E) Verrucarin $\mathrm{K}$

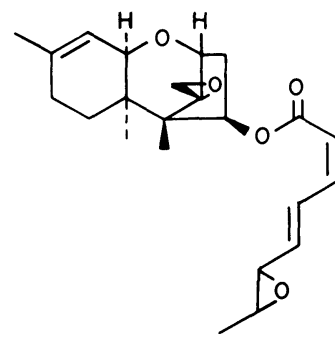

(F) Trichodermadiene

Fig. 5. Major trichothecenes 
grain intoxication in Japan, and that satratoxin $H$ and other related toxins caused stachybotryotoxicosis in Hungary and other Central European countries. The trichothecene toxicoses are commonly characterized by vomiting, feed-refusal, diarrhoea, dermal toxicity, inflammation and haemorrhage in intestines and muscle, malfunction of haemopoietic organs, and cellular destruction in the thymus, spleen, and other organs containing actively dividing cells.

The major trichothecenes are shown in Fig. 5. The trichothecene mycotoxins possess a common skeleton, the 12,13-epoxy-trichothecene nucleus. This 12,13-epoxy ring is presumed to be the functional group determining their toxicity and biological activity. The LD 50 values of $\mathrm{T}-2$ toxin, one of the toxic metabolites of $\mathrm{F}$. sporotrichioides, is $10.5 \mathrm{mg} / \mathrm{kg}$ in mice (per os), $3.06 \mathrm{mg} / \mathrm{kg}$ in guinea pigs (per os), and $5.2 \mathrm{mg} / \mathrm{kg}$ in rats, respectively. Newborn mice are extremely susceptible to the trichothecenes. Another interesting finding is the higher toxicity of $\mathrm{T}-2$ toxin when given subcutaneously as compared to other routes (ref. 17).

The trichothecenes exhibit various toxicological activities, but the mode of action is not fully clarified at the moment. Diarrhoea is often observed in the natural trichothecene toxicoses and in animal experiments. The mycotoxins may increase the permeability of blood vessel walls and intestinal mucosal epithelium and thereby cause leakage of plasma into the intestinal lumen, which eventually leads to diarrhoea. As for the dermal toxicity, the vascular permeabiljty in rabbits increased biphasically after skin application of the toxin and is present even after pretreatment with indomethacin or promethazine (ref. 17). Recently, markedly increased lipid peroxidation was observed in the liver of rats after T-2 toxin administration. This mechanism may also be associated with the injury of biomembranes of target organs (ref. 18).

Nivalenol and other trichothecenes are potent inhibitors of protein synthesis in eukaryotic cells (ref. 19). This biochemical feature is closely related to their potent cytotoxic effects and immunosuppressive action. The binding of trichothecenes to the 605 subunits of ribosomes, causes an interference with protein synthetic processes.

The metabolism of trichothecenes are classified into 1) deacylation; 2) hydroxylation, and 3 ) de-epoxidation. Fig. 6 summarizes the metabolic pathway of T-2 toxin in animal tissues. The microsomal carboxyesterases attack the linkage of the $C-4$ acetyl residue, and the resulting $H T-2$ toxin is further deacylated to T-2 tetraol via 4-deacetylneosolaniol. These deacylated metabolites are far less active that $T-2$ toxin. Another pathway of T-2 toxin metabolism is the hydroxylation of the C-8 isovaleroxy residue (ref. 20). T-2 toxin and HT-2 toxin are hydroxylated by microsomes into 3'-hydroxy-T-2 and HT-2 toxin, respectively. It is presumed that these hydroxylated metabolites remain in tissues.

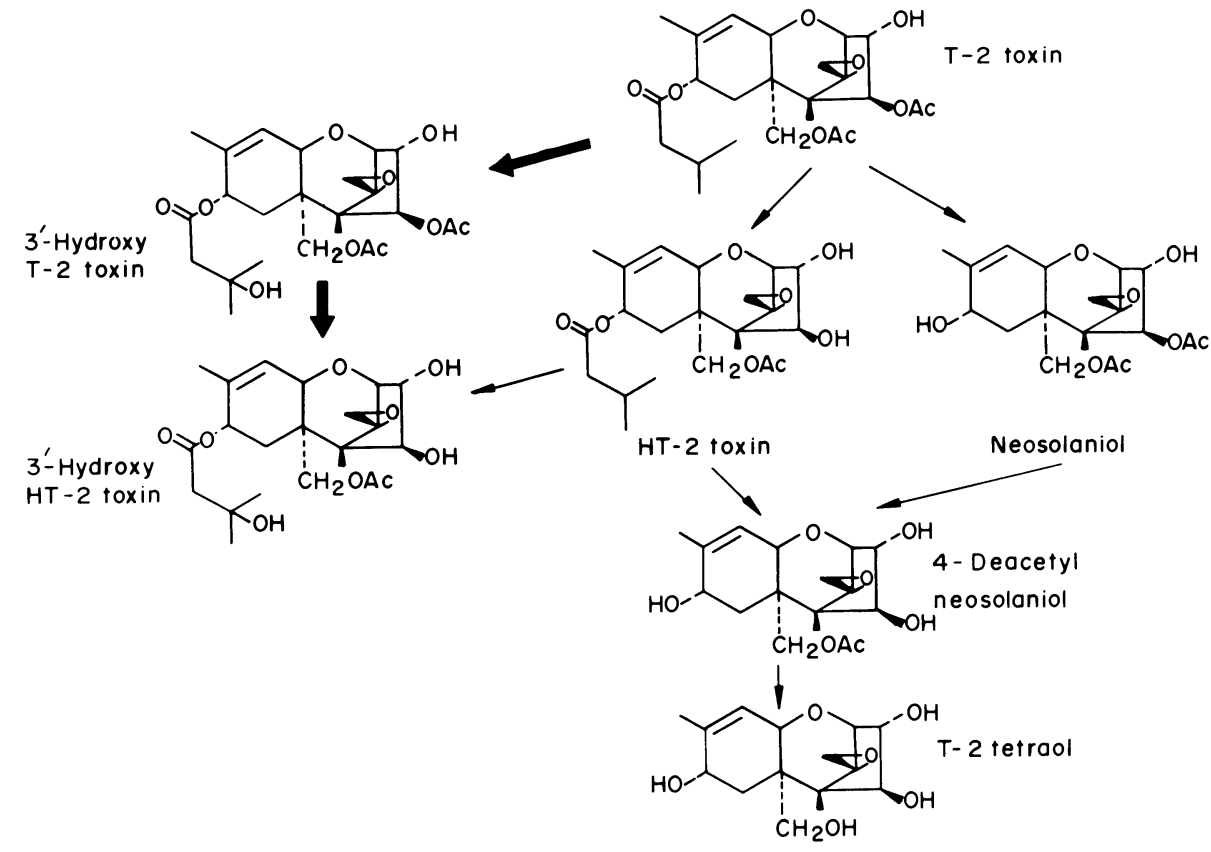

Fig. 6. Metabolic transformation of $\mathrm{T}-2$ toxin 
Upon incubation with dermal microflora under anaerobic conditions, deoxynivalenol changed into a new metabolite. Chemical analysis revealed that the 12,13 -epoxide ring was reduced to a vinyl bond (ref. 2l) (Fig. 7).

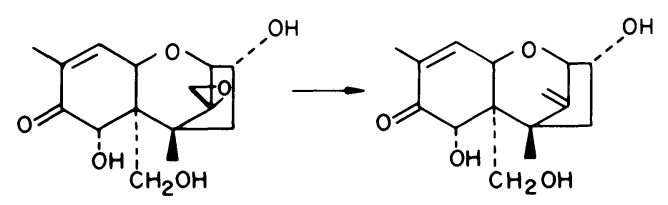

Fig. 7. De-epoxidation of deoxynivalenol

Since the 12,13-epoxide $r$ ing is essential for the toxicity of trichothecene mycotoxins, this de-epoxidation reaction is considered to be very important in the evaluation of trichothecene problems. It is possible that all the 12,13-epoxytrichothecene compounds are converted into their respective de-epoxidized metabolites by anaerobic dermal flora.

Currently, various physical methods such as TLC, GLC, GC/MS, and MS/MS are used for the detection and quantification of the trichothecenes which contaminate food- and feedstuffs. Accumulated data reveal that both nivalenol and deoxynivalenol ( $F i g .5, B$ ) are present in cereals such as barley, wheat, corn and their processed products in Japan, Korea and other countries, while deoxynivalenol is the sole contaminant found in the United States, Canada, England, and South Africa (ref. 22, 23). Beside these trichothecenes, an oestrogenic mycotoxin, zearalenone, produced by $F$. graminearum, coexists in cereals. Therefore, the author is convinced that the occurrence of these Fusarium mycotoxins (nivalenol, deoxynivalenol, and zearalenone) in cereals and their consequent presence in commerical foods, is one of the great hazards to man in respect of natural mycotoxin contamination.

\section{Modifiers of cytoskeletons}

C.l. Chloropeptide (Cyclochlorotine)

P. islandicum Sopp, one of the causative fungi of yellow rice toxicosis, produces two hepatotoxic mycotoxins: one is luteoskyrin (Fig. 2) which is present in the mycelia, and the other is the chloropeptide, present in the culture medium (Fig. 8) (ref. 24). The latter hepatotoxin is composed of $L-s e r i n e, L-\beta$-phenyl- $\beta$-aminopropionic acid, $L-\alpha$-aminon-butyric acid, and L-dichloroproline in the molar ratio of 2:1:1:1. Upon treatment with ammonia, it changes into a linear peptide which is non-toxic to animals. The $L D_{50}(\mathrm{mg} / \mathrm{kg})$ j.s 0.40 (intravenously), 0.45 (intraperitoneally) and 5.0 (per os) in mice. In isolated hepatocytes, this cyclic peptide at a low concentration $(0.1-0.2 \mu \mathrm{g} / \mathrm{ml})$, induces balloons or blebs (ref. 25). In vitro experiments have revealed an association of the toxin with purified actin; chloropeptide changes the actin fibers into a "stressed state". This physicochemical modification of the cytoskeleton induces the morphological changes of exposed cells. Therefore, it is presumed that this type of toxin is an excellent tool for the analysis of the function of cytoskeletal fibers in cells. The high affinity of the cyclic peptide for the hepatocytes is one of the reasons for the selective hepatocel lular damage (ref. 26).<smiles>CC[C@H]1NC(=O)C2C(Cl)CN(C(=O)C(CO)NC(=O)CC(c3ccccc3)NC(=O)[C@H](CO)NC1=O)C2C(Cl)Cl</smiles>

Fig. 8. Chloropeptide

\section{C.2. Cytochalasins}

More than 40 cytochalasin derivatives including phomin, zygosporin, and chaetoglobosin, are produced by various fungal genera (ref. 27,28 ). The basic skeleton of the cytochalasins (CC) is an isoindole ring with a benzyl, 3-indolyl methyl, or isobutyl residue at $\mathrm{C}-3$; 11 , or 13 -member $\mathrm{N}$-containing ring at $\mathrm{C}-8$, 9; or 13- or 14-membered 
0-containing ring at $\mathrm{C}-8,9$. Fig. 9 shows the structure of cytochalasin $\mathrm{B}$, one of the representative members of the cytochalasins. The LD 50 of CC-E in rats is 9.10 (per os) and 2.60 (intraperitoneally) $\mathrm{mg} / \mathrm{kg}$. The most prominent clinical signs are coma and an accumulation of oedema fluid at the injection site. A marked decrease of plasma albumin content in association with the damage to blood capillaries is followed by death due to shock (ref. 29).

CC is widely employed in experimental cell biology because of its inhibition of locomotion and cytoplasmic cleavage (cytokinesis) which causes nuclear exclusion. Yahara et al. (ref 30) observed the structure-activity relationship of $24 \mathrm{CC}$ derivatives, and the data revealed that $\mathrm{CC}$ inhibits locomotion of cells and induces ballooning of cells by induction of the contraction of actin fibers.

Another activity of $\mathrm{CC}$ is the inhibition of the glucose transport system in animal cells; this effect is marked when CC-B ( $F i g .9)$ is used. Of the two transport systems, the sodium ion-dependent transport of glucose is not affected by CC-B, while the sodium ionindependent system is inhibited by this toxin. The binding of $C C-B$ to a glucose transporter, which is a polypeptide of MW 54000 , has been clarified (ref. 31 ).

These findings indicate that $\mathrm{CC}$ is an excellent tool for toxicological approaches to the elucidation of the functions of the cytoskeleton and glucose transporter.<smiles>C=C1C(C)C([C@H](Cc2ccccc2)NC(=O)O)[C@]2(CCCC(C)C/C=C/CC[C@H](O)/C=C/C(=O)O2)C(C)C1O</smiles>

Fig. 9. Cytochalasin B

\section{Mutagens and carcinogens}

A variety of fungal metabolites are mutagenic and carcinogenic to animals. Long-term feeding experiments have revealed that aflatoxin, sterigmatocystin, versicolorin $A$, ochratoxin $A$, and luteoskyrin are carcinogenic. Since sufficient amounts of toxic metabolites are difficult to obtain for animal experiments, several short-term tests for assessing potential carcinogenicity offer important tools for the evaluation of these natural toxins. In this respect, the Rec-assay with recombination-deficient mutant cells of Bacillus subtilis (ref. 32), the Ames/microsomes test with Salmonella typhimurium (ref. 33, 34), and others, have been introduced. Most of the bisdihydrofuran mycotoxins such as the aflatoxins, sterigmatocystins, and versicolorins are potent mutagens to bacterial and mammalian cells. Recently, the author has proved the mutagenicity of emodin (Fig. 2 ), one of the polyhydroxyanthraquinones (ref. 35). This mycotoxin is only mutagenic in the presence of S-9 and a microsomal activation system. Chemical analysis of the active principle(s) revealed that, of more than a dozen metabolites, 2-hydroxy-emodin (Fig. 2) exhibits mutagenicity without the aid of the activation system (ref. 36). Free-radicals derived from 2-hydroxy-emodin are responsible for its genotoxicity.

It has been well established in environmental carcinogenesis that the cytochrome P-450 system plays an important role in the activation of mutagens and carcinogens. Of the numerous isoenzymes of cytochrome P-450s fractionated from PCB-treated rat livers, cytochrome P-450 I-a, which possesses a maximal CO-differential spectrum at $450.0 \mathrm{~nm}$, catalyzed the activation of aflatoxin $B_{1}$ into DNA-binding form(s). This epoxidation reaction is accelerated by cytochrome $b_{5}$ (ref. 37 ). Thus, the reconstituted cytochrome $\mathrm{P}-450$ system composed of cytochrome $\mathrm{P}-450$, NADPH-cytochrome P-450 reductase $\left(f \mathrm{P}_{T}\right)$, cholate, phospholipids, and others, is valuable for the evaluation of mutagenicity and related metabolic activation process of genotoxic chemicals (ref. 38). The hydroxylation of aflatoxin $B_{1}$ to aflatoxin $M_{1}$ and ochratoxin $A$ to $4(R)-4$-hydroxy-OT $A$ is catalyzed by chytochrome $\mathrm{P}-448$, and the transformation of emodin into 2-hydroxy-emodin is presumed to be catalyzed by cytochrome P-448 types.

Another method for evaluation of the genotoxicity is the hepatocyte primary culture/DNA repair test using rodent hepatocytes. Besides the carcinogenic mycotoxins such as af latxon $B_{1}$, sterigmatocystin, luteoskyrin, and ochratoxin $A$, several compounds of unknown carcinogenicity such as 5,6-dimethylsterigmatocystin, versicolorins $A$ and $B$, averufin, xanthomegnin, luteosporin, and chrysarin, are positive in this test system (ref. 39). 


\section{PHYCOTOXINS}

\section{A Cytoskeleton modifiers}

Sporadic toxin blooms of Microcystis aeruginosa have been responsible for several instances of animal poisoning in South Africa, Australia, Canada and other countries. Elleman et al. (ref. 40) isolated the cyclic peptide composed of an equimolar quantity of L-methionine, L-tyrosine, D-alanine, D-glutamic acid, erythro- $\beta$-methyl aspartic acid, and methylamine. The $\mathrm{LD}_{50}$ of the purified toxin to mice was estimated to be $0.056 \mathrm{mg} / \mathrm{kg}$, and parenteral administration produced extensive liver lobular haemorrhage and death within 1-3 hours. Repeated dosage of sublethal amounts of the toxin over several weeks produced progressive hepatocyte degeneration and necrosis and hepatic fibrosis. In vitro experiments with isolated hepatocytes revealed the deformation of hepatocellular membranes, similar to that caused by phalloidin and chloropeptide (Fig. 8) (ref. 41). These findings indicated an association of the toxin with actin. Botes et al. (ref. 42) isolated four toxins from this alga. Another cytoskeleton modifier is stypoldione, an oxidation product of stypotriol obtained from the brown alga Stypopodium zonale.

\section{B Tumor promoters}

Swimmer's itch was reported in Japan in the summer of 1968 at the Okinawa islands. The symptoms were itching, rash, burning, blisters and deep erosions, leaving a painful skin. A marine blue-green alga, Lyngbya majuscula, was suspected to be the cause of this dermatitis (ref. 43). Similarly, in the summer of 1980 , there was a severe outbreak of swimmer's itch on Oahu Island, Hawaii. Aplysiatoxin and debromoaplysiatoxin were isolated from this marine blue-green alga ( $L$. majuscula) (Fig. 10) (ref. 44, 45). These toxins were also detected in the toxic sample of the culture of Okinawa blue-green alga (ref. 46). This is the first report that humans are directly affected by these potent environmental tumor promoters in Japan.

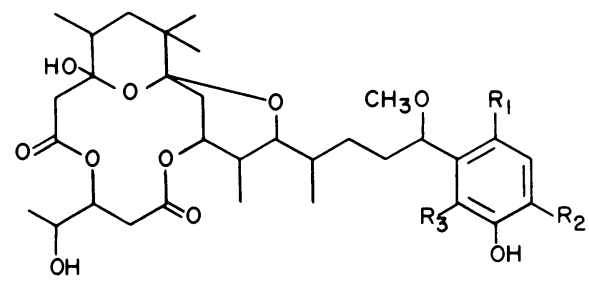

Debromoaplysiatoxin Aplysiatoxin Bromoaplysiatoxin Dibromoaplysiatoxin

$\begin{array}{lll}\mathrm{R}_{1} & \mathrm{R}_{2} & \mathrm{R}_{3} \\ \mathrm{H} & \mathrm{H} & \mathrm{H} \\ \mathrm{Br} & \mathrm{H} & \mathrm{H} \\ \mathrm{Br} & \mathrm{Br} & \mathrm{H} \\ \mathrm{Br} & \mathrm{Br} & \mathrm{Br}\end{array}$<smiles>[R]c1ccc(O)cc1C(O)CCC(C)C(OCC1OC(CC(=O)OC(CC(=O)OC(C)C([R2])O)C(C)C)=C(C)CC1(C)C)C(C)C</smiles>

Anhydrodebromoaplysiatoxin Anhydroaplysiatoxin Anhydroaplysiatoxin A

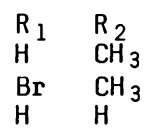

Fig. 10. Aplysiatoxins

In vivo experiments with three biological tests (irritation of mouse ear, induction of ornithíne decarboxylase in dorsal skin of mice, and inhibition of specific binding of $\left[{ }^{3} \mathrm{H}\right]$ 12-0-tetradecanoylphorbol-13-acetate (TPA) to an epidermal particular fraction) have revealed that of the 12 aplysiatoxin compounds, bromoaplysiatoxin and oscillatoxin $A$ (Fig. 1l) showed strong responses in the three biological tests, suggesting that these toxins should be tumor promoters in vivo, and that the C-3, C-20, and C-30 hydroxyl groups of the aplysiatoxins are involved in binding to the specific receptor of TPA (ref. 47).<smiles>CCCC(O)c1cccc(O)c1</smiles>

Oscillatoxin A<smiles>CCC(OCCC(OC(=O)CC(OC(=O)C=C1OC(C)(O)CC(C)(C)C1C)C(C)O)C(C)C)c1cccc(O)c1</smiles>

Oscillatoxin B

Fig. 11. Oscillatoxins 
It is noteworthy that TPA (besides being a well-known promoter) and other marine and microbial products such as aplysiatoxins of the blue-green alga, palytoxins from a coelenterate, Palythoa tuberculosa from Okinawa, and teleocidins from Streptomyces mediocidicus, possess common biologica! features characterized by dermal toxicity and tumor promotion activity (ref. 48).

\section{Hemolytic compounds}

The phytoflagellate Prymnesium parvum is notorius for producing toxins with ichthyotoxic and hemolytic activities inducing mass mortality of fish in brackish water culture ponds (ref. 49). Kozakai et al. (ref. 50) separated the toxic components into six substances by TLC. The major component named hemolysin I was a mixture of l'-0-octadecatetraenoyl-3'$0-(6-0-\beta-D-$ galactopyranosyl- $\beta-D$-galactopyranosyl)-glycerol and 1 '-0-octadecapentaenoyl-3'$0-(6-0-\beta-D$-galactopyranosyl- $\beta$-D-galactopyranosyl)-glycerol (Fig. 12). Amphidinium klebsii is also known to produce potent hemolytic compounds with a high molecular weight. The hemolytic activity of hemolysin I is 1250 times higher than that of saponin.

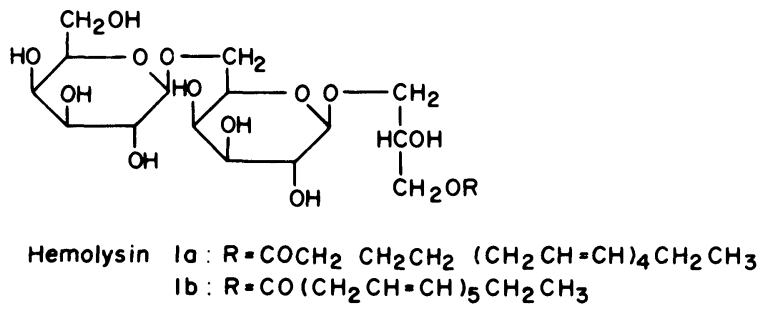

Fig. 12. Hemolysins

\section{Neurotoxins}

Bloom of Ptychodiscus brevis (formerly Gymnodinium breve) is responsible for massive fish killings in the Gulf of Mexico and along the Florida coast (ref. 51). The red tides are also associated with human intoxication resulting from ingestion of contaminated shellfish or inhalation of aerosols. A number of toxins have been isolated and purified to homogeneity by several groups. The chemical structures of two of the toxins, brevetoxin-B and $-C$, are shown in Fig. 13, and the nomenclature of the toxins are listed in Table 1.

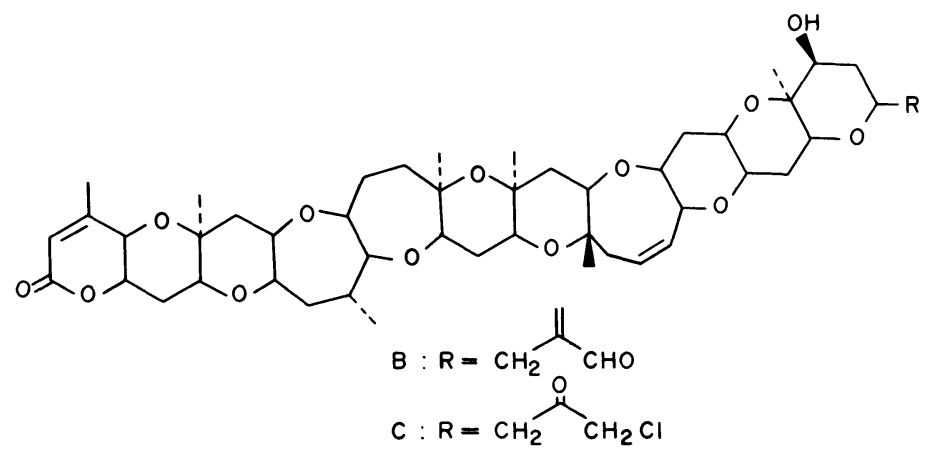

Fig. 13. Brevetoxins

TABLE 1. Nomenclature of brevetoxins (from ref. 57)

\begin{tabular}{lccc}
\hline $\begin{array}{l}\text { Lin et al. } \\
\text { (ref 52) }\end{array}$ & $\begin{array}{l}\text { Risk et al. } \\
\text { (ref.53) }\end{array}$ & $\begin{array}{l}\text { Baden et al. } \\
\text { (ref. 54) }\end{array}$ & $\begin{array}{l}\text { Shimizu et al. } \\
\text { (ref.55) }\end{array}$ \\
\hline $\begin{array}{l}\text { Brevetoxin A } \\
\text { Brevetoxin B }\end{array}$ & $\mathrm{T} 4-6$ & & $\mathrm{~GB}-1$ \\
(Dihydrobrevetoxin B) & $\mathrm{T} 4-7$ & $\mathrm{~T}-34$ & $\mathrm{~GB}-2$ \\
Brevetoxin C & & $\mathrm{T}-17$ & $\mathrm{~GB}-3$ \\
(Golik et al.) (ref. 56) & & & \\
\hline
\end{tabular}


Brevetoxins consist of a long carbon chain forming 11 contiguous ether rings, all fused trans to one another. Unlike saxitoxin and the gonyautoxins, which contain two guanidinium groups, the brevetoxins do not contain nitrogen at all and are highly lipidsoluble. Pharmacological investigations into the neurotoxicity in so-called "neurotoxic shellfish pojsoning" revealed that the brevetoxins depolarize the membrane by selectively opening sodjum channels at fairly negative potentials and by inhibiting the fast sodium inactivation. The binding site for brevetoxins is different from those for tetrodotoxin and sea anemone toxin (ref. 57).

\section{E Paralytic toxins}

The prevalence of paralytic shellfish poisoning (PSP) in tropical and subtropical waters has only become known in recent years. Worth et al. (ref. 58) first reported outbreaks of a PSP-like shellfish poisoning in Papua New Guinea in association with a red tide caused by a dinoflagellate Pyrodinium bahamense (later amended to $P$. bahamense var. compressa). The chemical nature of the causative toxins, however, was not clarified until Yasumoto's group identified toxins of the saxitoxin family in Palauan specimens of the same species of dinoflagellate as well as in bivalves infested with the organism (ref. 59). This flagellate produces gonyautoxins $V, V I$ and a new toxin PBT (= decarbamoylsaxitoxin). In order to elucidate the natural occurrence of these toxins in suspected fishes, bivalves (Spondylus butleri) were collected at Arumizu Bay, Palau, where P. bahamense var. compressa was endemic. From $1.05 \mathrm{~kg}$ of the bivalve meat, $4.9 \mathrm{mg}$ of PBT and $22 \mathrm{mg}$ of saxitoxin (STX) were isolated (ref.60). This is the first report to confirm the occurrence of dcSTX in nature. The specific activity of PBT based on the mouse assay was 4200 mouse units per $\mathrm{mg}$, which is comparable to dcSTX ( 3700 units). STX was first isolated from the Alaskan butter clam (Saxidomus giganteus) and its LD 50 was estimated as $10 \mu \mathrm{g} / \mathrm{kg}$ (intraperitoneally), i.e. comparable to that of tetrodotoxin. Fig. 14 summarizes the structure of STX and gonyautoxins.
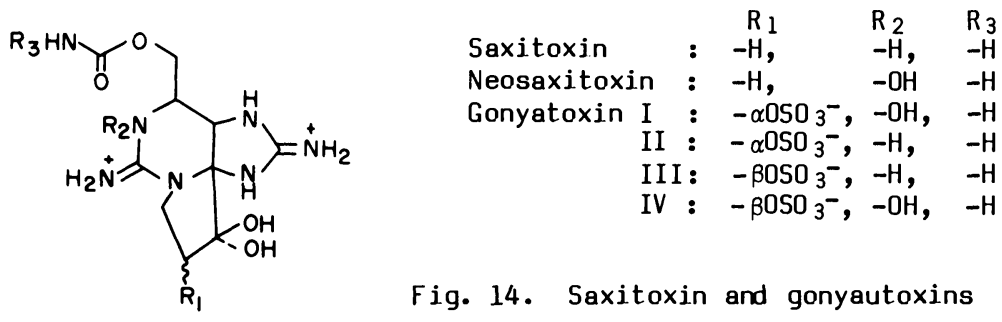

Fig. 14. Saxitoxin and gonyautoxins

Currently attention is focused on the potential transformation of gonyautoxins to STX. Upon incubation of gonyautoxin $V$ with gastric juice, $8-15 \%$ of the toxin was converted to STX with concomitant release of sulfate. Since the gonyautoxins are characterized by their $\mathrm{N}$-sulfonatecarbamoyl moiety, and by the fact that these $\mathrm{N}$-sulfonated toxins have a low lethal toxicity, this acid-catalyzed transformation to STX constitutes an important factor in the evaluation of their toxicity (Fig. 15).

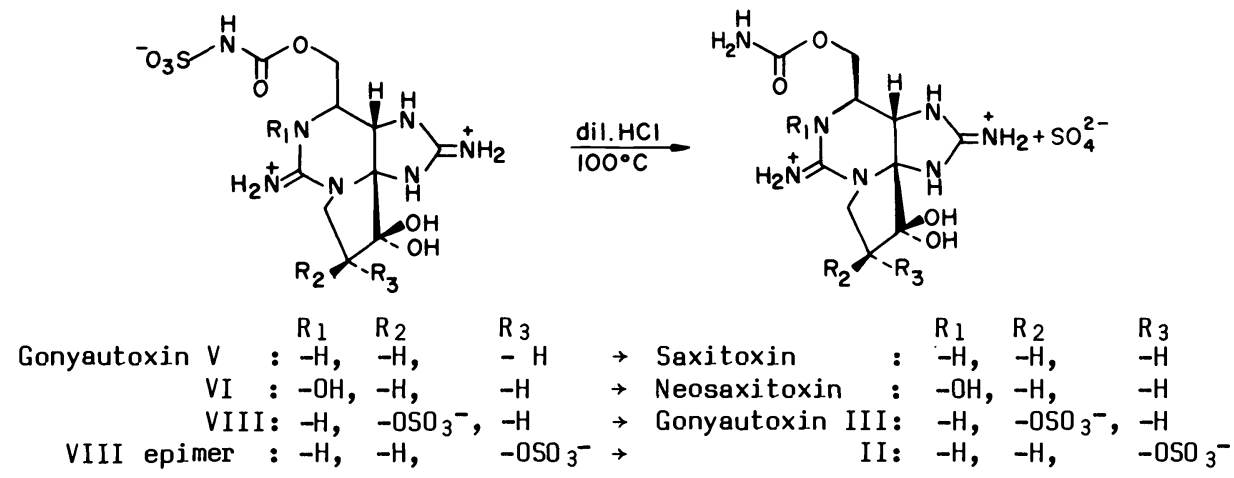

Fig. 15. Acid transformation of gonyautoxins (ref. 61)

\section{F Ciguatoxin and maitotoxin}

Ciguatoxin (CTX) is the causative agent responsible for food-borne intoxication by toxic fish in tropical and subtropical seas. This "ciguatera" intoxication was suspected to be induced by the ingestion of toxic microorganisms by fish. From the analysis of intestinal contents and feed of fish in the Gambier islands of Polynesia where the massive occurrence of "ciguatera" was often recorded, the alga-attached dinoflagellate, Gambierdiscus toxicus, was identjfied as the causative organism. From hot-methanol extracts of samples, 
CIX and maitotoxin (MTX) were fractionated from the lipophilic and water-soluble fractions, respectively. CTX is the major toxin in mussels and MTX is detected in the liver and viscera of toxic fish (ref. 62, 63).

CTX is one of the most toxic of the marine toxins, and the LD 50 is reported to be $0.45 \mu \mathrm{g} /$ $\mathrm{kg}$. The minimal effective dose in man is $0.2 \mu \mathrm{g}$ and the LD50 of purified MTX in mice is $0.15 \mu \mathrm{g} / \mathrm{kg}$ (intra-peritoneally).

The chemical structure of CTX has only been partially determined by Tachibana (ref. 64). The molecular weight is about 1112 , and the molecular formula is presumed to be $\mathrm{C}_{53} \mathrm{H}_{77} \mathrm{NO}_{24}$ or $\mathrm{C}_{54} \mathrm{H}_{78} \mathrm{O}_{24}$. MTX is a high molecular weight compound composed of glucose, galactose and fatty acids.

CTX induces contraction of the isolated guinea pig vas deferens. This contraction is inhibited by phentolamine, reserpine, 6-hydroxydopamine or guanethidine, suggesting that the CTX-induced contraction is elicited by a release of catecholamine from the nerve endings (ref. 65). In the vas deferens, CTX non-specifically produces a significant potentiation of response to norepinephrine, acetylcholine and high potassium (ref. 66). This CTX-induced potentiation is assumed to be due to an increase in excitability of the post-synaptic membrane. Further investigations revealed that CIX has a potent depolarizing action which is due to a selective increase in $\mathrm{Na}^{+}$-permeability in nerve and muscle cells. Thus, CTX causes the nerve membrane to depolarize and inhibits the stimulation-induced action potential. These changes are followed by a decrease in the release of neuro-transmitters.

In contrast to the finding that CTX attacks the $\mathrm{Na}^{+}$-channels, MTX selectively activates the $\mathrm{Ca}^{++}$-channels. In cultured neuroblasts and other mammalian cells, MTX increases the $\mathrm{Ca}^{++}$-permeability of $\mathrm{Ca}^{++}$-channels and thereby causes the depolarization of the cell membrane. As is well known, the $\mathrm{Ca}^{++}$-channels have multiple forms in cell membranes, and contribute to physiological and pharmacological phenomena. In this respect, MTX is expected to be an excellent tool for analysing the function of $\mathrm{Ca}^{++}$-channels (ref. 67).

\section{G Diarrhoea-inducing shellfish toxins}

In north-eastern Japan, gastro-enteritis is frequently caused by the consumption of shellfish harvested during late spring to summer. The presence of acetone-soluble toxins in the digestive glands of the implicated shellfish, confirmed the gastro-enteritis to be an unknown type of shellfish poisoning. Hence this disease was named diarrhoea-inducing shellfish poisoning (DSP). Although no red tide was seen during the infestation period, the regional and seasonal variation of shellfish toxicity strongly suggested the planktonic origin of the intoxication. Later, a dinoflagellate Dinophysis fortii was identified as the organism which causes shellfish to become toxic (ref. 68).

During 1976-1983, more than 1300 cases of DSP were recorded in Japan, while 5000 patients in Spain in 1981, and 500 in France in 1984 were considered to have contracted this type of gastro-enteritis. DSP may thus be considered as one of the important problems in food hygiene in the world.

The major symptoms of DSP are diarrhoea and vomiting. No deaths were reported. From the digestive glands of shellfish, the toxic principle, dinophysistoxin-l was isolated. This toxin is a 35-methyl ester of okadaic acid, which is a $C_{38}$ polyether fatty acid derivative isolated first from sponges as a potent cytotoxic compound (ref.69, 70) (Fig. 16). Subsequent efforts revealed the presence of other okadaic acid derivatives, named dinophysistoxin-3, and novel polyether lactones, named pectenotoxins (PTX) after the generic name of the scallop (Fig. 17) (ref. 71).

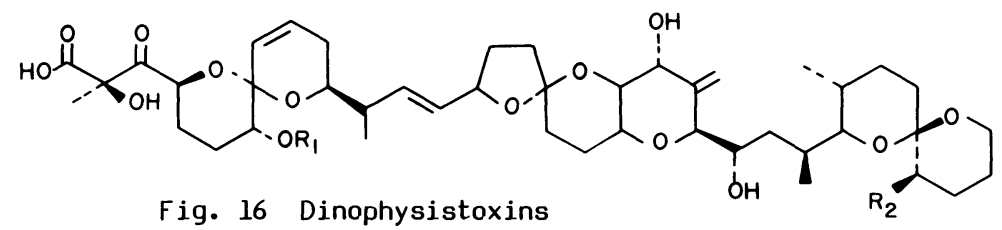

Fig. 16 Dinophysistoxins

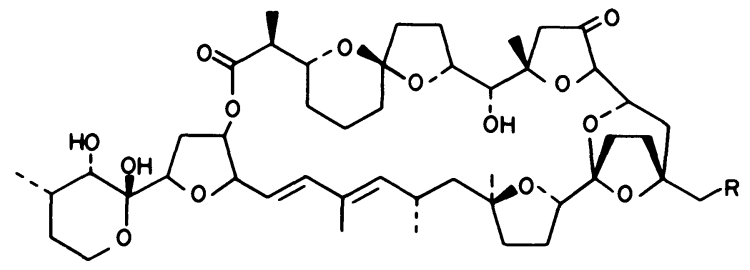

Okadaic acid:

$$
R_{1}=R_{2}=H
$$

Dinophysistoxin $-\mathrm{l}: \mathrm{R}_{1}=\mathrm{H}, \quad \mathrm{R}_{2}=\mathrm{CH}_{3}$ -3: $R_{1}=$ acryl, $\mathrm{R}_{2}=\mathrm{CH}_{3}$

Fig. 17 Pectenotoxins 
Although DSP was first confirmed in Japan as cited above, its occurrence has been shown to be more frequent and widespread than suspected earlier. Since the symptoms of DSP are relatively mild, and considered by many people to be a bacterial infection, a proper method is needed for detection of the toxins and diagnosis of this specific gastroenteritis. Recently monoclonal antibodies against okadaic acid were prepared and used in the ELISA method for detecting these toxins in fish. Oral intake of $32 \mu \mathrm{g}$ of dinophysistoxin-l causes j.llness in man, and we thus have to develop very sensitive (like the ELISA method) and specific methods for the detection of these toxins.

No detailed information is available at present concerning the biological action mechanism of these toxins, but several preliminary reports revealed that okadaic acid induces contraction of the smooth muscle of rabbjts and guinea pigs. This effect is presumed to be a direct effect on the muscle fibers. Indomethacin does not inhibit okadaic acidinduced contraction of the muscle (ref. 71). This finding may suggest that the diarrhoegenic action of the toxin is different from those of cholera toxin and other bacterial toxins. Experiments with enteropooling assays in newborn mice revealed that dinophysistoxin-l increased the amount of intestinal water, while no increase was observed with pectenotoxin-l. Further study is needed for elucidation of these diarrhoegenic toxins in the development of shellfish poisoning in man (ref. 72).

Recently, D. acuminata was also proven to produce the okadaic acid derivatives in Japanese mussels. A similar compound was detected in Dutch mussels exposed to this dinoflagellate. The incidence of gastro-enteritis caused by ingestion of mussels in Chile was associated with the occurrence of Dinophysis acuta (ref. 70). Therefore, further research on the production of polyether toxins by other species of Dinophysis is required for clarification of the sporadic outbreaks of gastro-enteritis.

\section{REFERENCES}

1. K. Uraguchi, J. stored Prod. Res., 5, 227-236 (1969).

2. R.B. Beechey, D.0. Osselton, R.E. 'Linnett and A.D. Mitchell, Membrane Protein in Transport and Phosphorylation (Eds. G.F. Azzone, M.E. Klinggerberg, E. Quengliariello and N. Sj.liprandi) Elsevier, 201-204 (1974).

3. Y. Ueno, Mycotoxins: Production, Isolation, Separation, and Purification (Ed. V. Betina) Elsevier, 329-350 (1984).

4. K. Kawai, Y. Nozawa, Y. Maebayashi, M. Yamazaki and T. Hamazaki, Appl. Environ. Microbiol., 47, 481-843 (1984).

5. K. Kawai, M.L. Cowger and Y. Nozawa, Proc. Jpn. Assoc. Mycotoxicol., 15, 22-24 (1982).

6. K. Kawai, H. Shiojiri, T. Nakamaru, Y. Nozawa, S. Sugie, H. Mori, T. Kato and Y. Ogihara, Cell Biol. Toxicol., 1, 1-10 (1985).

7. R.J. Cole, J.W. Kirksey, H.G. Cutler, B.J. Doupnik and J.C. Peckham, Science, 179, 1324-1326 (1973).

8. P.G. Thiel, Biochem. Pharmacol., 27, 483-486 (1978).

9. P. Krogh, Mycotoxins in Human and Animal Health (Eds. J.V. Rodricks, C.W. Hesseltine and M.A. Mehlman) Pathotox, 489-498 (1977).

10. H. Meisner, M.A. Cimbala and R.W. Hanson, Arch. Biochem. Biophys., 223, 264-270 (1983).

11. R. Röschenthaler, E.E. Creppy, H. Dreismann and G. Dirheimer, Proc. Jpn. Assoc. Mycotoxicol., 18, 24-27 (1983).

12. F.C. Stormer, O. Storen, C.E. Hansen, J.I. Pedersen and A.J. Aasen, Appl. Environ. Microbiol., 45, 1183-1187 (1983).

13. Y. Ueno, S. Yamada, T. Onda and S. Yoneda, 104th Ann. Meet. Jpn. Pharm. Soc. (1984).

14. Y. Ueno, Adv. Nutr. Res., Vol. 3 (Ed. H.H. Draper) Plenum, 301-353 (1980).

15. Y. Ueno (Ed.), Irichothecenes: Chemical, Biological and Toxicological Aspects, Elsevier (1983).

16. J.R. Bamburg, Prog. Mol. Subcell. Biol. (Ed. F.E. Hahn) Springer-Verlag, Vol 8., 41-110.

17. Y. Ueno, Found. Appl. Toxicol., 4, S124-S132 (1984).

18. M. Tsuchida, T. Miura, T. Shimizu and K. Aibara, Biochem. Med., 31, 147-166 (1984).

19. Y. Ueno, M. Hosoya, Y. Morita, I. Ueno and T. Tatsuno, J. Biochem. (Tokyo), 64, 479-485 (1968).

20. T. Yoshizawa, T. Sakamoto and K. Okamoto, Appl. Environ. Microbiol., 47, 130-134 (1984).

21. R.R. King, R.E. McQueen, D. Levesque and R. Greenhalgh, J. Agric. Food Chem., 32, 1181-1183 (1984).

22. T. Tanaka, A. Hasegawa, Y. Matsuki, K. Ishii and Y. Ueno, Food Additives Contami., 2, 125-137 (1985).

23. U.-S. Lee, H.-S. Jang, T. Tanaka, A. Hasegawa, Y.-J. Oh and Y. Ueno, Food Addj.tives Contami., in press (1985).

24. Y. Ueno, Mycotoxins: Production, Isolation, Separation and Purification (Ed. V. Betina) Elsevier, 475-480 (1984).

25. Y. Ueno, Y. Tanaka, K. Sato, K. Sakakibara, T. Tachibana and A. Tanaka, J. Toxicol. Sci., $\underline{9}, 117-130(1984)$. 
26. Y. Ueno, T. I to and S. Nonomura, 72nd Jpn. Soc. Pharmacol. (Tokyo), (1985).

27. S.W. Tanenbaum (Ed.) Cytochalasins: Biochemical and Cell Biological Aspects, North-Holland, 1978.

28. S. Natori, Mycotoxins in Human and Animal Health (Eds. J.V. Rodricks, C.W. Hesseltine and M.A. Mehlman) Pathotox, 559-581 (1977).

29. T. Glinsukon, R.C. Shank, G.N. Wogan and P.M. Newberne, Toxicol. Appl. Pharmacol., 32, $135-146$ (1975).

30. I. Yahara, F. Harada, S. Sekita, K. Yoshihira and S. Natori, J. Cell Biol., 92, 69-78 (1982).

31. L.J. Wardzala and B. Jeanrenaud, Biochem. Biophys. Acta, 730, 49-56 (1983).

32. Y. Ueno and K. Kubota, Cancer Res., 36, 445-451 (1976).

33. F.C. Wehner, P.G. Thiel, S.J. van Rensburg and I.P.C. Demasius, Mutation Res., 58, 193-203 (1978).

34. Y. Ueno, K. Kubota, T. Ito and Y. Makamura, Cancer Res., 38, 536-542 (1978).

35. T. Masuda and Y. Ueno, Mutation Res., 125, 135-144 (1983).

36. T. Masuda, K. Haraikawa, N. Morooka, S. Nakano and Y. Ueno, Mutation Res., 149, 327-332 (1985).

37. Y. Ueno, K. Ishii, Y. Omata, T. Kamataki and R. Kato, Carcinogenesis, 4, 1071-1073 (1983).

38. Y. Ueno, F. Tashiro, K. Haraikawa and Y. Emi, Problems of Threshold in Chemical Mutagens (Ed. Y. Tazima). 61-71 (1984).

39. H. Mori, K. Kawai, F. Ohbayashi, T. Kuniyasu, T. Hamazaki and G.M. Williams, Cancer Res., 44, 2918-2923 (1984).

40. T.C. Elleman, I.R. Falconer, A.R.B. Jackson and M.T. Runnegar, Aust. J. Biol. Sci., $31,209-218$ (1978).

41. M.T. Runnegar, I.R. Falconer and J. Silver, Arch. Pharmacol., 317, 268-272 (1981).

42. D.P. Botes, H. Kruger and C.C. Viljoen, Toxicon, 20, 945-954 ( $\overline{1982})$.

43. Y. Hashimoto, H. Kamiya, K. Yamazato and K. Nozawa, Animal Plant Microb. Toxins, 1 , 333-338 (1976).

44. R.E. Moore, Pure Appl. Chem., 54, 1919-1934 (1982).

45. R.E. Moore, A.J. Blackman, C.E. Cheuk and J.S. Mynderse, J. Org. Chem., 49, 2484-2489 (1984).

46. H. Fujiki, K. Ikegami, H. Hakii, M. Suginuma, Z. Yamazumi, K. Yamazato, R. Moore and T. Sugimura, Jpn. J. Cancer Res. (Gann), 76, 257-259 (1985).

47. M. Suganuma, H. Fujiki, T. Tahira, C. Cheuk, R.E. Moore and T. Sugimura, Carcinogenesis, 5, 315-318 (1984).

48. H. Fujiki, M. Suganuma, T. Tahira, A. Yoshioka, M. Nakayasu, Y. Endo, K. Shudo, S. Takayama, R.E. Moore and T. Sugimura, Cell. Interact. Environ. Tumor promotors (Ed. H. Fujiki), Jpn. Sci. Soc. Press. 37-45 (1984).

49. M. Shilo, Bacterial Rev., 31, 180-193 (1967).

50. H. Kozakai, Y. Oshima and T. Yasumoto, Agric. Biol. Chem., 46, 233-236 (1982).

51. T.M. Mende and D.G. Baden, Trends Biochem. Sci., 3, 209-211 (1978).

52. Y.-Y. Lin, M. Risk, S.M. Ray, D.V. Engen, J. Clardy, J. Golik, J.C. James and K. Nakanishi, J. Am. Chem. Soc., 103, 6773-6775 (1981).

53. M. Risk, Y. Y. Lin, R.D. MacF arlane, V.M. Sadagipa-Ramanujam, L.L. Smith and N.M. Trieff, Toxic Dinoflagellate Blooms (Eds. D.L. Taylor and H.H. Seliger), Elsevier, 335-344 (1979).

54. D.G. Baden, T.J. Mende and R.E. Block, Toxic Dinoflagellate Blooms (Eds. D.L. Taylor and H.H. Seliger), Elsevier, 327-334 (1979).

55. Y. Shimizu, M. Alam and W.E. Fallow, Red-tide Toxins (Eds. H.H. Webber and G.D. Ruggieri), Marine Technology Soc., 238-251 (1976).

56. J. Golik, J.C. James and K. Nakanishi, Tetrahedron Lett., 23, 2535-3538 (1982)

57. J.M.C. Huang, C.H. Wu and D.G. Baden, J. Pharm. Exp. Ther., 229, 615-621 (1982).

58. G.K. Worth, J.L. Maclean and M.J. Price, Pacific Sci., 29, 1 (1975).

59. T. Harada, Y. Oshima and T. Yasumoto, Agric. Biol. Chem., 46, 1866-1874 (1982).

60. T. Harada, Y. Oshima and T. Yasumoto, Agric. Biol. Chem., 47, 191-193 (1983).

61. T. Harada, Y. Oshima and T. Yasumoto, Toxicon, 22, 476-478 (1984).

62. P.J. Scheuer, W. Takahashi, J. Tsutsumi and T. Yasumoto, Science, 155, 1267-1268 (1967).

63. M. Nukina, L.M. Koyanagi and P.J. Scheuer, Toxicon, 22, 169-176 (1984).

64. K. Tachibana, Ph.D. dissertation, University of Hawaii (1980).

65. Y. Ohizumi, S. Shibata and K. Tachibana, J. Pharmacol. Exp. Ther., 217, 475-480 (1981).

66. Y. Ohizumi, Y. Ishida and S. Shibata, J. Pharmacol. Exp. Ther., 221, 748-752 (1982).

67. Y. Ohizumi, A. Kajiwara and T. Yasumoto, J. Pharmacol. Exp. Med., 227, 119-204 (1983).

68. T. Yasumoto, Y. Oshima, W. Sugawara, Y. Fukuyo, H. Ogura, T. Igarashi and N. Fujita, Bull. Jpn. Soc. Sci. Fish., 46, 1405-1411 (1980).

69. M. Murata, M. Shimatani, H. Sugitani, Y. Oshima and T. Yasumoto, Bull. Jpn. Soc. Sci. Fish., 48, 549-552 (1982).

70. T. Yasumoto, M. Murata, Y. Oshima and M. Sano, Tetrahedron, 4l, 1019-1025 (1985).

71. S. Shibata, Y. Ishida, H. Kitano, Y. Ohizumi, J. Habon, Y. Tsukitani and H. Kikuchi, J. Pharmacol. Exp. Ther., 223, 135-143 (1982).

72. T. Yasumoto, Kaiyo-Kagaku, 16, 600-604 (1984) (in Japanese). 